\title{
$\begin{array}{llllll}D & O & S & S & I & \hat{E}\end{array}$ $\begin{array}{llllll}V & I & R & A & D & A\end{array}$ AFETIVA
}

\section{DÉJÀ-VU DE SENSAÇÕES EM UMA AULA DE DANÇA}

Lula Borges ${ }^{\Perp}$

\begin{abstract}
RESUMO
Este é um texto voltado para uma experiência de dança moderna, feita por um professor-dançarino de Israel Ofir Yudilevitch, especialmente convidado para uma aula no Departamento de Artes da Universidade Federal do Rio Grande do Norte (UFRN) no ano de 2018. Aqui faço descrição de como foi a aula e registro como tudo aconteceu naquela aula, em formato de desenhos esquemáticos, mas, além disso, descrevo também a sensação de já ter vivido aqueles momentos e, a partir dessa sensação, falar um pouco sobre o falso reconhecimento, a sensação de déjà-vu. Para me dar suporte no que escrevo, uso das palavras de educadores e pensadores como Bergson (2006), Freire (1996), Bondía (2002) e Fernandes (2001), que, de alguma forma, ajudam a elucidar as linhas aqui escritas.
\end{abstract}

\section{Palavras-chave:}

dança; educação; déjà-vu; arte.

\section{ABSTRACT}

This paper is about a modern dancing experience, made by a dancer-teacher from Israel, Ofir Yudilevitch, specially invited for a classroom at the Department of Arts of the Federal University of Rio Grande do Norte (UFRN), in the year 2018. Here is the description about the classroom, in the format of schematic drawings, but, I also registered the sensation of my graduating life lived through those moments and my sensations about it, that is recognized like false preconception, a sensation of déjàvu. To support about my words, I searched of educators and thinkers like Bergson (2006), Freire (1996), Bondia (2002) and Fernandes (2001), which, in some form, can elucidate the words written here.

\section{Keywords:}

dance, education, déjà-vu; art. 


\section{Dosite $V$ I $R$ R A $A$ D A AFETIVA}

\section{INTRODUÇÃO}

A busca pela experiência em sala de aula é uma máxima procurada pelos professores, desde sempre. Quero deixar claro que, experiência nesse caso seria a busca da prática, pois de elementos teóricos as salas estão cheias, mas quando o aluno passa por algum tipo de experiência, que enfatize o que vera nos livros, aquilo nunca mais sairá de sua cabeça. Bondía (2002), faz um texto sobre o assunto e afirma que a partir desse duo, teoria/ prática, o estudante tem o que chamamos de “"reflexão" e expressões como "reflexão crítica", "reflexão sobre prática ou nãoprática", "reflexão emancipadora", etc.". (BONDÍA, 2002, p. 151) Precisamos, cada dia mais, procurar o dualismo ou dialogismo (FREIRE, 1996) entre as duas pontas da compreensão de um aprendizado. As aulas de artes são as que podem fazer isso quanto ao aprendizado, mas outras disciplinas também, no entanto, pelo fator vivência, objetivo minhas palavras para esta matéria.

O professor também deve ter esse dualismo. Não adianta estar dentro de laboratórios nas universidades, fazer seu curso e sair do mesmo dizendo que é licenciado. Se você não tem uma mínima vivência com o que você vai destinar em suas aulas, com alunos que não tem o mínimo de discernimento sobre sua disciplina, como você pode tornar-se um bom professor, ou mesmo um professor melhor a cada ano lecionado? Durante minha graduação em arte, tive o prazer de vivenciar várias das teorias e técnicas para poder explicar aos alunos como produzir um elemento artístico e o contexto que aquilo foi criado. Isso em escultura, pintura, música, entre tantas disciplinas que um professor "polivalente" podia ter naquelas aulas dos idos anos de 1990 e vai aqui uma crítica de como as aulas, hoje, com disciplinas de artes em apenas uma linguagem (dança, teatro, música ou visuais) pode fazer um professor sofrer mais em seus primeiros anos de aula. A polivalência é necessária em cursos de graduação de artes. Depois, com as especializações, o professor pode se dedicar a linguagem que queira.

Das disciplinas que paguei, uma que ficou gravada na minha mente foi a de dança. Não sou dançarino, nem imagino que algum dia eu venha a ser. Mas as experiências criadas a partir do que se passava naquelas noites com o professor Edson Claro e, principalmente, Eládio 


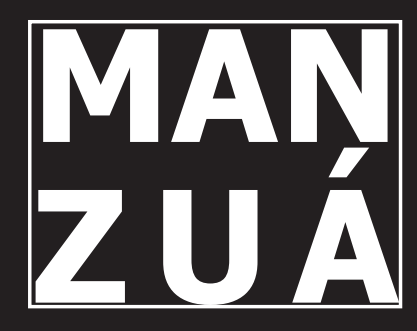

\section{DosSI

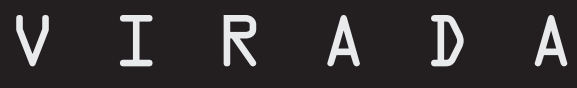 AFETIVA}

Barbosa $^{2}$, fez-me mudar o meu modo de ver a vida, como perder minha timidez ou ser mais ágio com meus pensamentos ou mesmo o corpo ao se trabalhar na academia, na sala de aula ou mesmo no mercado de trabalho. Experiência essa que, ao ser aceito no curso de mestrado e ter, como primeira cadeira, Experiências e práticas do ensino de artes na escola, com o professor Doutor Marcílio Vieira, voltado para o teatro, me fez voltar no tempo e parecer que estava, novamente, vivenciando aqueles dias e que, a partir das próximas linhas repasso essas sensações a você, leitor.

Com as aulas do Mestrado Profissional de Artes pela UFRN, no ano de 2018, início de agosto, tivemos nossa primeira aula. Uma aula morna, claro, apenas para que os dissentes falassem um pouco das suas experiências artísticas e pedagógicas, além da razão de se fazer um curso de mestrado. O professor da turma, naquela aula discutiu sobre como seriam distribuídas as noites das terças, dia das aulas, pois o mesmo, por ser atarefado, não poderia ministrar todas as noites daquela disciplina voltada para a experiência de nós artistas, em sala de aula, mas que deixaria direcionamentos para que pudéssemos fazer atividades nesses dias que não pudéssemos trocar experiências dentro das quatro paredes do Departamento de Artes da UFRN, além dos textos que comumente são dados para que os alunos possam estudar e fazer seu trabalho de fim de disciplina.

As próximas linhas, podem ser vistas como um estudo de caso, leitor, e foi algo imprescindível, para que o assunto em questão pudesse aflorar, ou este artigo/ ensaio poderia não ter sido criado, haja vista que um acontecimento fez outro vir à tona em minha consciência.

A primeira das atividades sobre experiências foi logo na segunda aula, o qual nós iríamos visualizar uma aula de dança de um estrangeiro que estava na cidade convidado por um grupo de dança da capital. Não nego que não gostei da ideia, pois cursos de pós-graduação são, normalmente, direcionados para questões teóricas e, se íamos ter essas trocas de experiência em sala de aula, que

2 - Dois professores do Departamento de Artes de UFRN nos anos 1990, o primeiro, professor de dança, o segundo, apesar de ser da área de engenharia, era professor do departamento de educação e, no nosso caso, de fundamentos do teatro. 


\section{Dosite $V$ I $R$ R A $A$ D A AFETIVA}

fosse de forma tradicional, especialmente em um primeiro momento. No entanto, por se tratar de "experiência", e, por essa atividade ter sido algo determinada antes do início das nossas aulas, imaginei que poderíamos, sim, desfrutar daquela experiência, levando em consideração que é justamente isso que estamos estudando no semestre. Visitar aulas de outros artistas, analisar o conteúdo do mesmo, verificar a aceitação (ou não) dos alunos para aquela disciplina, ou aula especial.

Antes do procedimento da aula, na semana anterior, havia-me acometido de alguns problemas pessoais que me fizeram rever algumas prioridades para minha vida, mas principalmente, o acidente. Sou músico. Toco contrabaixo desde os 17 anos, ou seja, 30 anos dedicado à música que, por ser um trabalho coletivo, sempre estive envolvido com muitos tipos de pessoas e, por fim, os grupos musicais que estou envolvido, sempre tem algum problema, principalmente. Decidi sair do mundo da música após alguns problemas (que sempre acontecem) e, voltando daquele último ensaio, o carro, em plena avenida, simplesmente travou os pneus traseiros, ficando atravessado no meio da faixa numa hora de muito movimento.
No entanto, fiquei imaginando se tivesse acontecido o mesmo, eu estando em uma velocidade maior. Seria um desastre.

Talvez, a uma primeira leitura, isso não pareça importante para você, leitor, mas tudo fará sentido a partir de agora, pois por não andar mais no carro, estava a pé, tive que ir de ônibus para a universidade no dia da aula sobre dança, ou seja, igual como fazia quando ia as aulas na graduação, me fazendo perceber de forma diferente o que acontecia ao redor dos meus passos. Por estar próximo à rodovia de acesso (BR 101), desci ao lado do Departamento de Artes e segui até o mesmo. Atravessando a avenida, me veio a sensação de repetir algo que já tinha feito antes. Passara toda minha graduação naquele departamento e ia sempre de ônibus, a caminhada me fez quase que retornar ao passado subindo aquele morrinho para chegar ao departamento. Tudo hoje está mudado no local, mas a sensação ficou em cada passo dado.

Chegando no prédio, logo fui acompanhado por Luiz Elson, exprofessor de desenho e, agora, colega de turma no curso. Fomos convidados para retirar os tênis para poder entrar na sala de aula, guardamos os tênis próximos 


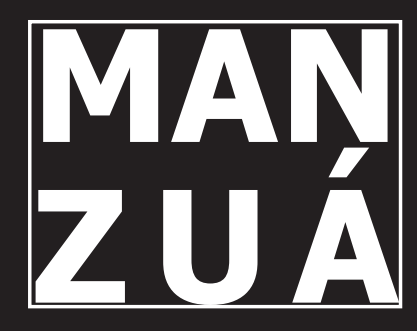

\section{O S S I E $V$ I R A D $A$ AFETIVA}

a porta e entramos, com o seu piso de madeira e muito ventilada. Novamente tive a sensação de repetir-se algo ao meu redor. As trocas de roupa, os aquecimentos e alongamentos dos alunos. Fiquei vendo todo o movimento. Sentei-me próximo a uma das paredes e peguei o caderno para fazer anotações. Não sabia como seria a aula, mas percebia que já havia passado por aquela situação. Minha mente voltou vinte anos no tempo, quando eu próprio fazia as oficinas de dança e de teatro e para tal, precisava fazer aqueles mesmos movimentos, alongamentos, aquecimentos numa sala direcionada a dança e ao teatro.

Algum tempo depois, com os alunos do professor estrangeiro prontos e alguns da nossa própria turma também participando, iniciou-se a aula. $\mathrm{O}$ professor em questão é Ofir Yudilevitch, dançarino de uma companhia de dança de Israel, que estava em Natal/RN para um evento de dança que ocorreu em parceria de grupos de três países, Brasil, Alemanha e seu país natal. Um projeto da Solo Connection de Alemanha, Bönisch Produções Culturais (BPC), do Brasil e a Suzanne Dellal Centre, de Israel, que promovem intercâmbio cultural entre artistas da dança contemporânea brasileira e israelense ${ }^{3}$. Yudilevitch foi um dos três dançarinos que vieram de Israel e foi convidado pela Universidade Federal do Rio Grande do Norte (UFRN) para mostrar suas experiências em dança e participar, com os alunos, dos exercícios que o mesmo propunha. Interessante observar sua pouca dificuldade em falar português que foi amplamente auxiliado por uma das alunas do curso, quando havia algo mais complexo para explicar. A forma de falar a língua apesar do modo característico de americanos falarem, me veio à mente que, na verdade ele é dos países Árabes, então ele tinha que pensar em sua língua nativa, traduzir para o inglês e quando conhecia palavras em nosso idioma traduzia direto para o português. Creio que para algumas pessoas isso daria um nó na sua cabeça, mas a aula fluiu com tranquilidade.

\section{MODUS OPERANDI}

Logo no início da aula, todos os alunos participantes ficaram distribuídos

3 - Mais informações podem ser encontradas na rede social da Bonisch dentro do Facebook no seguinte link: https://www.facebook.com/bpcproducoes/, acessado em 11 de outubro de 2018. 


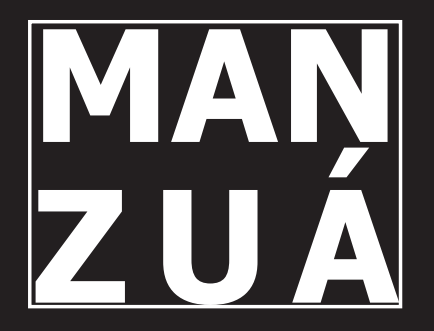

\section{$\begin{array}{llllll}D & O & S & S & I & \hat{E}\end{array}$

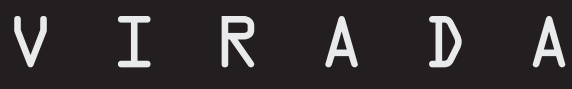 AFETIVA}

em um grande círculo, enquanto outros que não participaram efetivamente da atividade, ficaram mais próximos das paredes, alguns com câmeras e celulares para as fotos da aula, outros, como eu e Luiz Elson, falado acima, empunhamos nossos lápis e caderno para anotações e desenhos, para alguns casos que fossem necessários. O professor começou a discursar sobre aquele dia de aula, pois a semana inteira seria dado aulas sobre dança e aquele era o segundo dia. Nosso professor, Marcílio Vieira, que coordenava essa aula prática, foi ao sistema de som e colocou algumas músicas, assim como Ofir Yudilevitch. As músicas eram calmas e normalmente em língua inglesa, quando cantadas.

A partir daí, os alunos iniciaram uma série de aquecimento (alguns já o faziam antes da aula), mas aquecimento criado pelo professor até chegar ao ponto de estarem todos fazendo os exercícios práticos, a partir do que ele discorria. O primeiro movimento foi ele deitar-se decúbito dorsal com as pernas esticadas e os braços em forma de "A", $\mathrm{fez}$ pequenos movimentos de sobe-edesce na horizontal (já que ele estava deitado), com movimentos rápidos mas não acelerados, o movimento exigia rolar também a cabeça, de forma que ela subia e descia, como um "sim" que o professor fazia. Os dois movimentos, do corpo e da cabeça pode ser visto no esquema que desenhei e que aparece na figura 1 . Todos os alunos que estavam na prática, repetiram o movimento. Para os que tiveram dificuldades de subir e descer o corpo com a pena esticada, o professor pediu para dobrar as pernas para poder plantar o pé no chão e assim, ter força para levar o corpo. Também pediu observância

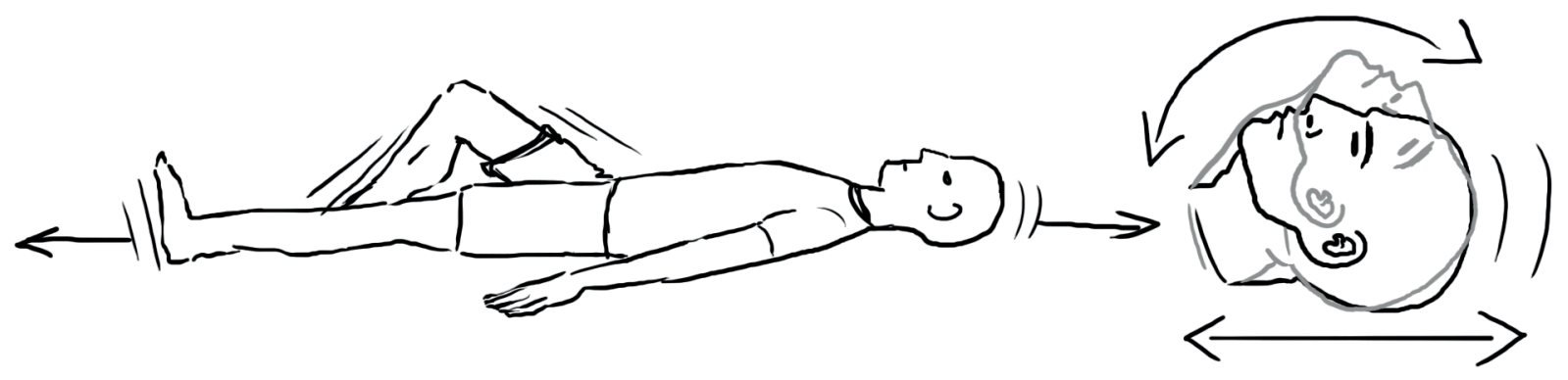

Figura 1: Movimento deitado de sobe-e-desce. A cabeça fica levantando também, conforme movimento do corpo. Arte do autor. 


\section{$\begin{array}{llllll}D & O & S & S & I & \hat{E}\end{array}$ $V$ I $R$ A $A$ A AFETIVA}

no movimento da cabeça, pois alguns alunos tinham ficado com a mesma parada. Todos ficaram de pé após o exercício.

Em outro exercício, todos tinham que forçar a respiração, inspirando $\mathrm{e}$ expirando rapidamente e profundamente e, novamente deitaram, mas desta vez decúbito frontal, pernas esticadas e braços esticados ao chão, acima da cabeça. Os braços então eram forçados a ficar de forma que pudessem subir o tronco (Figura 2-A). Primeiro o ombro e depois o resto até ficar da pélvis para cima, montado no braço, enquanto as pernas continuavam esticadas no chão. Mas elas também subiam e os alunos ficavam de quatro (Figura 2-B), novamente forçando a respiração. Interessante notar que a cabeça ficara o tempo todo baixa. Novamente o exercício de respiração foi executado, com eles nessa posição, mas a cabeça ficava sempre baixa. Após esse processo de inspiração e expiração, o novo movimento era esticar as pernas o mais distante possível, ficando apenas as mãos e pés no chão e o corpo todo esticado.
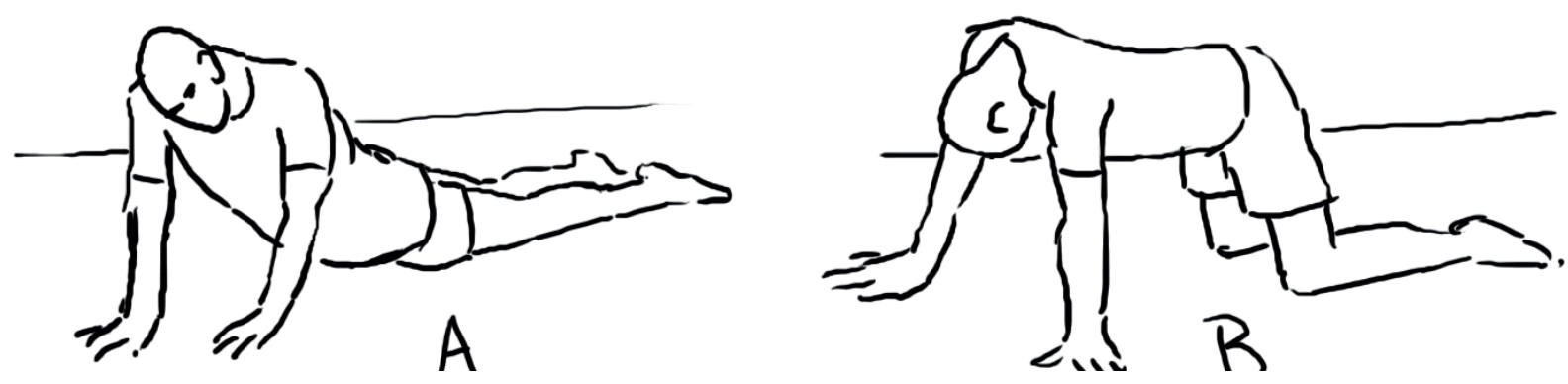

Figura 2: Subindo o corpo com os braços e pernas esticados. Arte do autor. 


\section{$\begin{array}{llllll}D & O & S & S & I & \hat{E}\end{array}$

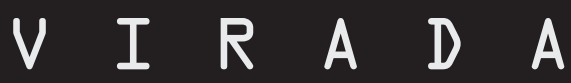 AFETIVA}

Novamente os alunos deitam decúbito dorsal e, com os braços esticados em "A", levantam a perna, deixandoas flexionadas por alguns segundos e, novamente os alunos faziam o movimento de sobe e desce do corpo e da cabeça. Da mesma forma, os alunos ficaram de quatro, fazendo o movimento de respiração, mas agora, usando todo o tórax e abdômen, no movimento de respiração e também o movimento de "sim" da cabeça, da seguinte forma: ao inspirar sobe o tórax e baixa a cabeça até o peito (ou no limite de cada estudante), ao expirar, desce o tórax e levanta a cabeça. Os movimentos eram rápidos. Mas dentro de uma cadência que a música influía neles. $\mathrm{O}$ esquema pode ser visto na figura 3.

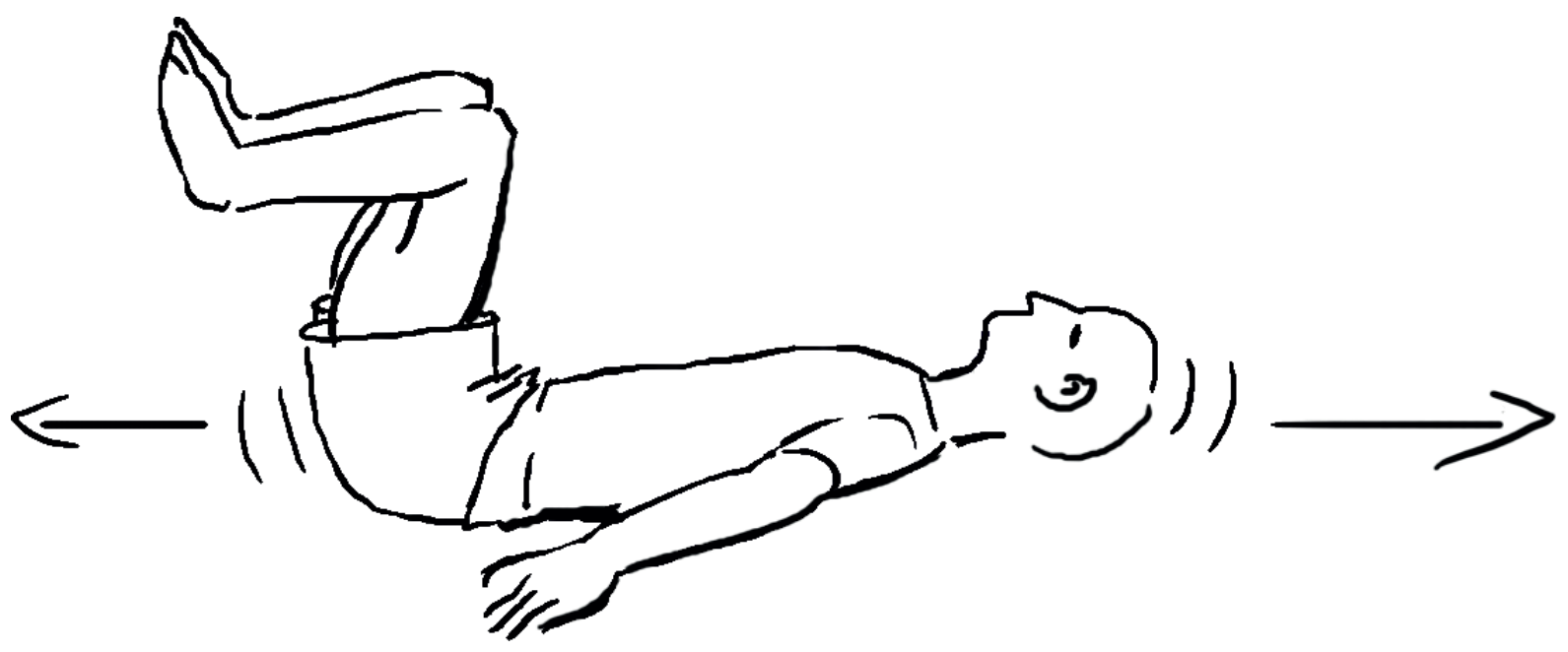

Figura 3: Movimento de vaivém, deitado, de braços abertos. Arte do autor. 


\section{MAN
ZUAA}

\section{D $\quad 0 \quad S \quad S \quad S \quad I \quad \hat{E}$ $V \quad I \quad R \quad A \quad D \quad A$ AFETIVA}

Novamente os alunos ficaram de pé e andaram pelo salão esticando as pernas. Nova explicação. Depois o professor instruiu-os a ficarem em pares para que fosse feito um novo exercício onde um aluno seguraria o peso do outro, em uma distribuição simétrica. Esse peso seria distribuído a partir das mãos. O parceiro passivo seguraria todo o peso do ativo apenas com as mãos, enquanto este forçaria a parte de cima do corpo para frente, deixando as pernas esticadas. Esse peso para a frente seria sustentado pelo passivo, conforme mostrado na figura 4 .

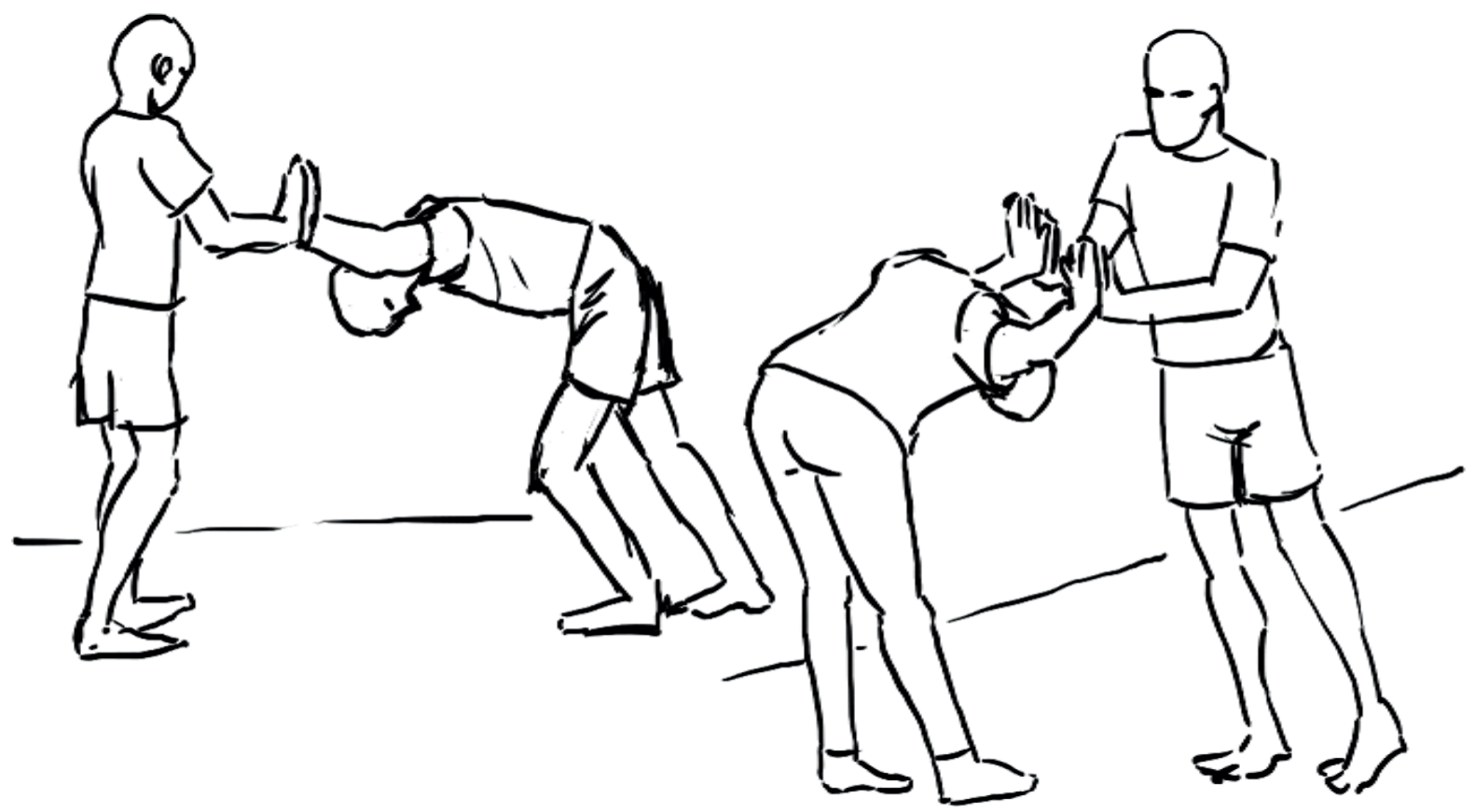

Figura 4: Força simétrica, sendo o corpo segurado pelas mãos dos parceiros. Arte do autor. 


\section{$\begin{array}{llllll}D & O & S & S & I & \hat{E}\end{array}$

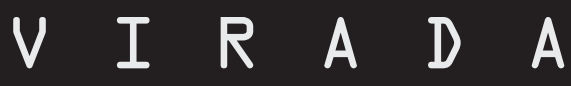 AFETIVA}

Novamente todos param e o professor volta a conversar sobre os micros movimentos do ombro e a cabeça, que deve ficar abaixada, enquanto o ombro é que faz os movimentos de vaivém. Mais uma vez todos se espalham pela sala e inicia-se novo exercício, onde, de cócoras, segurando as pernas, como se o corpo estivesse fechado em si mesmo, solta-se o braço, segurando as mãos no piso, fazendo o apoio do corpo ficar ali e, aos poucos, o corpo vai ficar aberto, fazendo-o ficar apoiado nos quatro membros, forçar todo o corpo, levando os pés para trás lentamente e levantando o quadril até o ponto do corpo ficar na forma de "A" (figura 5). Sempre com a cabeça baixa e sendo sustentando com os pés e as mãos. Ao chegar ao extremo do movimento, com a cabeça baixa, o estudante moveria apenas os ombros para cima e para baixo.
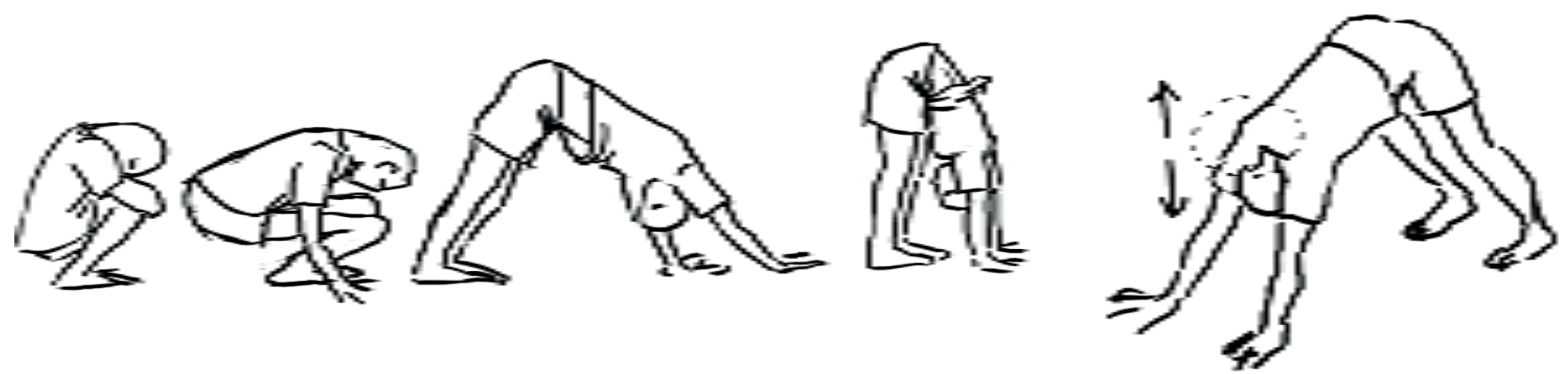

Figura 5: Corpo seguro com as mãos em forma de "A". Chegando ao extremo, move-se o ombro para cima e para baixo. Arte do autor. 


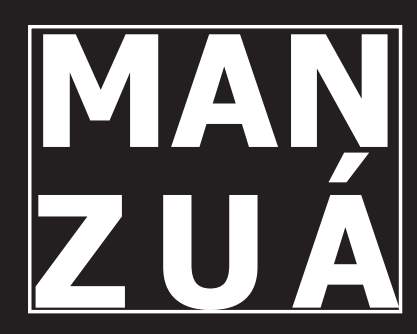

\section{$\begin{array}{llllll}D & O & S & S & I & \hat{E}\end{array}$ $V$ I $\quad R \quad A \quad D \quad A$ AFETIVA}

Todos esses exercícios foram feitos em um tempo que chega dos dois aos cinco minutos, então, os movimentos são lentos e, conforme um dos alunos que estavam na parte prática, apesar de se ver leveza nos movimentos, o estudante, na verdade, estava trabalhando com uma força imensa, para poder segurar o corpo por tanto tempo. Novamente o exercício é feito, mas desta vez, após mover o ombro, o corpo é jogado para trás, depois de chegar a forma "A", fazendo o corpo girar no chão, como um pneu, colocando as pernas para cima para poder fazer o giro e, se o aluno conseguisse fazer o movimento, voltaria a sua forma "fechada". Claro que alguns alunos não conseguiram e deixaram o corpo caído no chão, de lado, de frente, outros voltavam a perna, sem conseguir fazer o movimento até o fim, criando uma cena cômica a uma primeira impressão. Mas "isso faz parte do processo", conforme afirmou Yudilevitch, somos feitos de líquidos e essa é uma característica deles: se adaptam a toda forma. Percebe-se, aqui que o professor falava, necessariamente do método Laban que trabalha com a préexpressividade, o que Yudilevitch estava preparando os alunos e, a forma líquida, pois "todas as estruturas do corpo humano são irrigadas e conectadas por líquidos em movimento" (FERNANDES, 2001, p. 8). Assim, este exercício é um ciclo em si, como os líquidos também o são, pois estes se adaptam a todas as formas. O corpo, fechado, abre-se em "A", move-se o ombro, joga-se o corpo para trás, cai de costas no chão, com a força da queda, eleva-se as pernas e volta-se a forma fechada, de cócoras. 


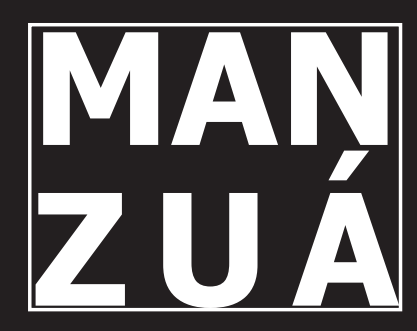

\section{$\begin{array}{llllll}D & O & S & S & I & \hat{E}\end{array}$

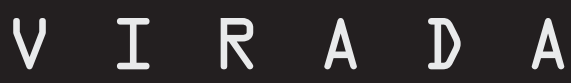 AFETIVA}

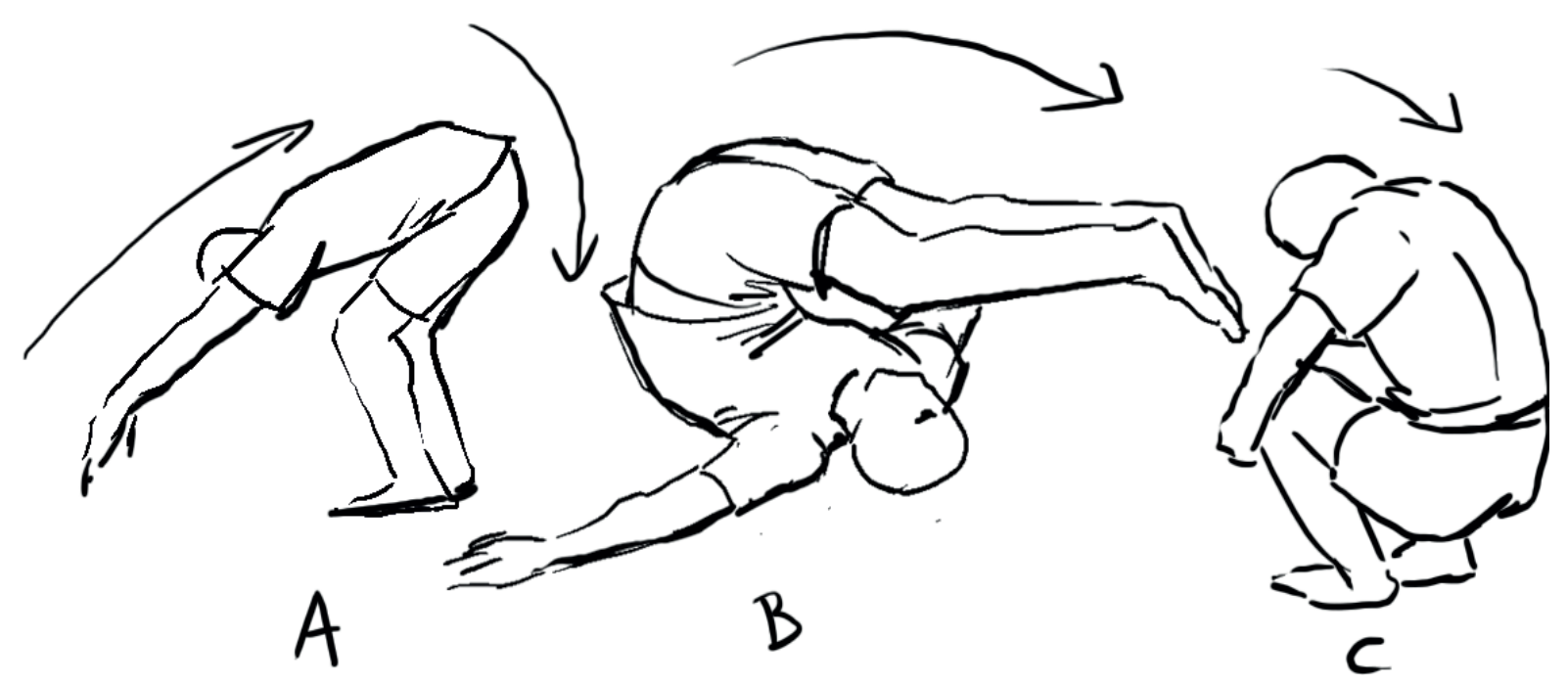

Figura 6: Voltando a ficar de cócoras, levando o corpo para trás, caindo de costas e levantando as pernas, voltando a posição de cócoras novamente. Arte do Autor.

Este, apesar ser um texto acadêmico e ter partes narrativas em muitas linhas, é necessariamente, um texto descritivo e este parágrafo é, certamente o mais complexo que poderei fazer aqui, pois este próximo exercício não é simples de explanar. Todos os alunos ficaram ao fundo da sala, em pé, escorados na parede, parecendo uma grande fila, aguardando o próximo passo que o professor faria. Esse exercício foi uma caminhada, a qual ele, andando na diagonal, dava-se dois passos para frente e esquerda, um passo para trás, voltando da esquerda para a direita, dois passos a esquerda, um passo para trás da esquerda para a direita, voltando novamente ao primeiro passo, que volta a dois passos à esquerda e assim por diante. Vendo o professor fazer aquele movimento, sozinho, vislumbrei quase um jogo de golpe de capoeira, mas, quando este pediu aos estudantes todos fazerem o mesmo movimento em trio, ai um balé tomou conta da sala. Enquanto os três primeiros faziam o segundo movimento (andar na diagonal para a direita) o segundo grupo 


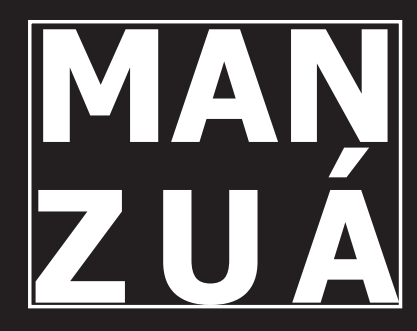

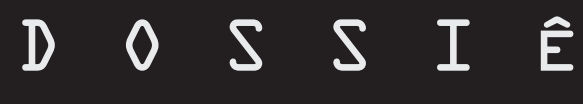 $V$ I $\quad R \quad A \quad D \quad A$ AFETIVA}

de três iniciavam o primeiro movimento, sendo que ao chegarem ao meio do salão, todos os alunos já estavam fazendo a movimentação e a dança fez-se aos nossos olhos de espectador. Ao menos foi o que notei. O som, sempre ligado com música calma, cantada em inglês, estava presente na parte que os alunos faziam. Novamente, veio-me a sensação de já ter vivido aquilo nas aulas de minha graduação, no entanto, eu tinha que focar no que ocorria na sala.

Mas esse foi apenas o exercício inicial, que, conforme Fernandes (2001) poder-se-ia ser chamado de pré-expressividade, que, apesar de ser evidenciado numa fase mais infantil dos humanos (nesse caso, inicial), serve para, ao se tornar adulto, seguir o que se aprendeu enquanto se era criança. Se fizermos um paralelo com o trabalho que estava sendo elaborado na sala, os alunos estavam, na verdade, fazendo pré-operações para, depois, a partir dos próximos exercícios, efetivar o que estavam descobrindo, aprendendo. O que deveria ser feito, a partir daquele momento, envolvia os movimentos iniciais que tentei descrever acima. Desta vez o movimento tinha nome "swing", onde dá-se os dois primeiros passos e, para voltar um passo, faz-se uma meia cambalhota, onde as pernas ficam suspensas no ar por um ou dois segundos, fazendo o corpo ficar em “T” e voltar (um passo), anda os dois passos para a direita, faz o " $T$ ”, volta, dois a esquerda, "T", volta e assim por diante. Esse movimento foi registrado com o esquema da figura 7. Uma observação a ser feita é que a cabeça sempre ficava baixa em todos os movimentos. Todos os alunos fizeram os movimentos em trio, novamente a sensação de um balé (ou dança contemporânea) veio à tona. Um mar de gente fazendo movimentos ao mesmo tempo, com os alunos andando toda a sala fazendo o passo. 


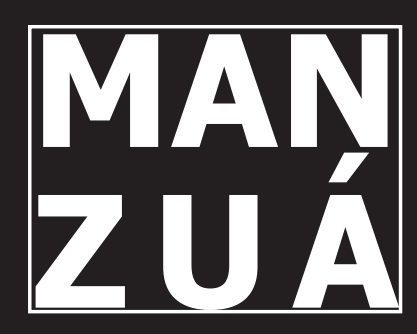

\section{$\begin{array}{llllllll}D & O & S & S & I & \hat{E}\end{array}$ $V \quad I \quad R \quad A \quad D \quad A$ AFETIVA}
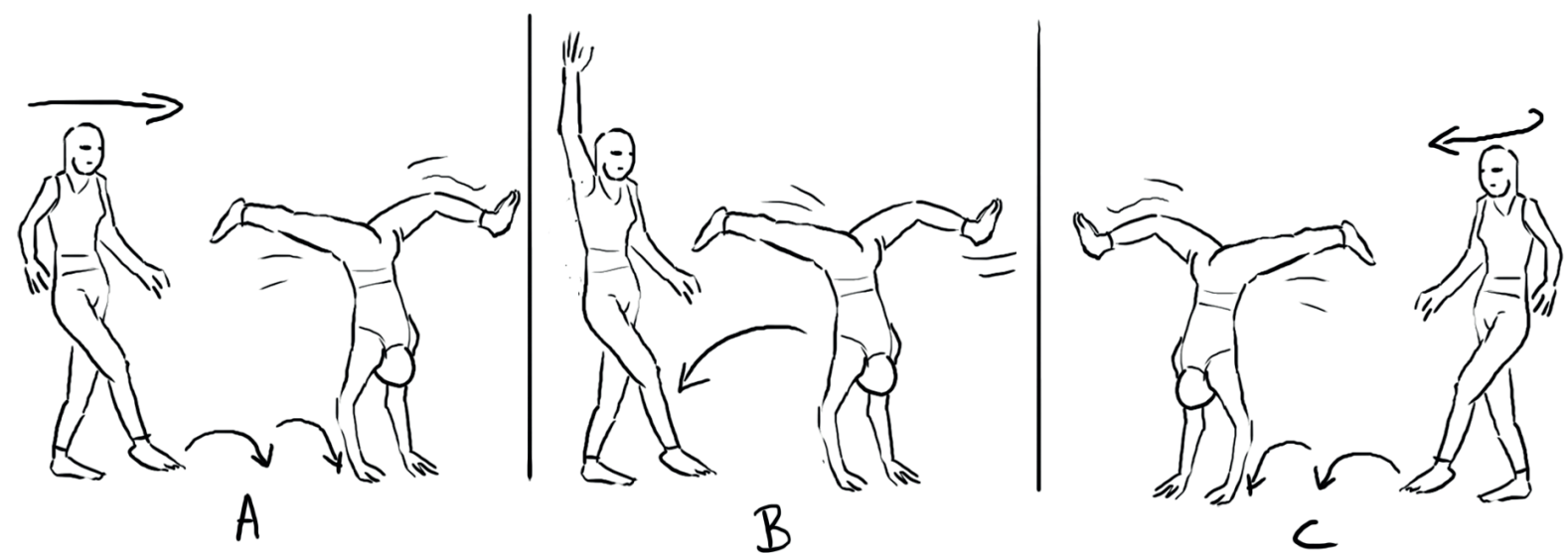

Figura 7: A. dois passos para a esquerda e faz meia cambalhota (fica parado, como fizesse um "T" com as pernas abertas. B. Volta um passo, saindo da meia cambalhota. C. Volta-se para o lado direito e faz o mesmo passo, repetindo até o fim do espaço que está sendo utilizado. Arte do autor.

Ainda outro exercício com o mesmo tipo de passo, com um andar mais rápido pela sala, dá-se os três passos para a esquerda, faz a cambalhota, para-se ao ar por fração de segundo, mas aí faz-se um giro com a perna que está em cima, neste caso a esquerda e a cambalhota faz-se completa, mas a primeira perna (esquerda) vai primeiro ao chão, pois o corpo todo deve fazer um movimento circular, a partir da força que a perna esquerda fez. Ao terminar essa parte, o aluno vai para a direita e faz o mesmo movimento, andando, nessa atividade, mais rapidamente pela sala de dança. A sensação, novamente que tive é que o exercício fazia parte de algum golpe de capoeira, tipo a meia-lua, mas ao ver todos fazendo a mesma coisa, percebi o bailar dos corpos pelo espaço. O esquema que fiz abaixo (figura 8) ilustra mais ou menos o que se passava, mas percebi, também, que o professor estava preparando os alunos para algo maior, pois os movimentos estavam cada vez mais complicados. $\mathrm{Eu}$ esperava o que viria pela frente e não largava o caderno para anotações $\mathrm{e}$ desenhos. 


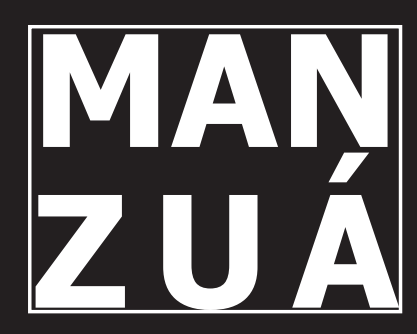

\section{$\begin{array}{llllllll}D & O & S & S & I & \hat{E}\end{array}$ $V \quad I \quad R \quad A \quad D \quad A$ AFETIVA}

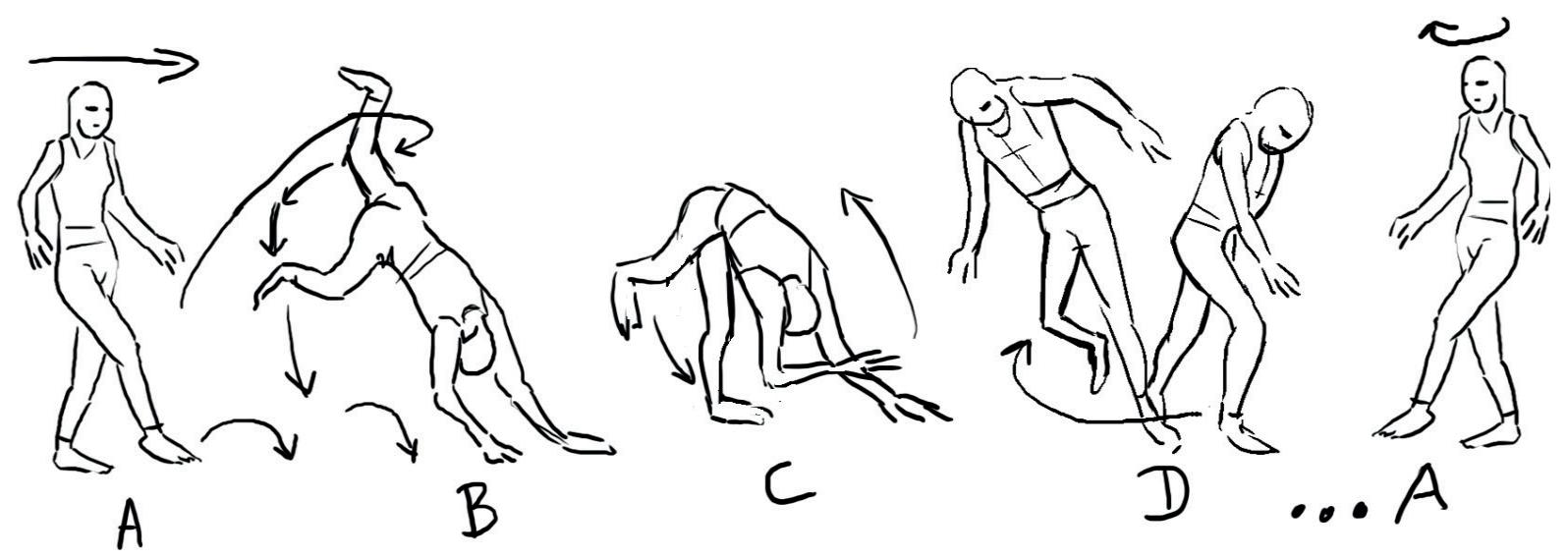

Figura 8: Ciclo para o "twist". Dois passos para a esquerde, faz a cambalhota e joga a perna esquerda ao ar. Ao descê-la, antes da perna direita, joga o corpo para trás e recomeça, mas agora indo para a direita, reiniciando-se o ciclo. Arte do autor.

Mas para minha frustração momentânea, o professor pediu para todos sentarem em círculo e, com seu linguajar entre inglês e português, falou que o próximo exercício seria simples, mas deveria ser feito com muito cuidado ou os alunos iriam machucar-se. Os movimentos deveriam ser muito lentos. $\mathrm{O}$ nome do exercício é "já foi” e, em pares, um dos dois, o passivo, ficaria imóvel, como um boneco e o outro moveria seu corpo em várias possíveis posições, inclusive levantando, deixando em pé, mas quem conduziria o corpo que "já foi” seria o companheiro ativo na atividade. O passivo não poderia (mesmo) ajudar

nos movimentos. O exercício, conforme Yudilevitch, ajuda a perceber melhor o corpo. Tanto o membro ativo quanto o passivo do par. Depois de cinco minutos, haveria a troca dos dois componentes. Feito a escolha de quem seria o primeiro, o passivo ficou no chão estirado, com as mãos próximas a cintura e o ativo começou a mover, levantar, puxar, baixar, erguer o colega. Quando soltava a parte do corpo, claro, o corpo seguia a força da gravidade. Mais uma vez um aluno falou que para fazer esse exercício, apesar de lento e parecer leve, a força para manter o corpo erijo era imensurável, pois para 


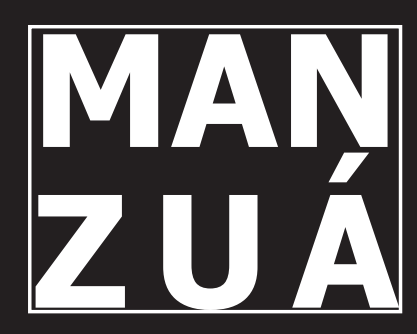

\section{$\begin{array}{llllll}D & O & S & S & I & \hat{E}\end{array}$ $V$ I $\quad R \quad A \quad D \quad A$ AFETIVA}

cada membro levado a algum lugar, ele, naturalmente, voltava a posição de descanso do corpo. Alguns alunos, por medo de cair ou machucar um braço ou perna ao voltar rapidamente ao solo, tensionava o braço. $\mathrm{O}$ professor chegou perto de alguns deles ao perceber o esse medo e dizia "você não está aqui", ou seja, "já foi”, "está morto”. Para os ativos, uma advertência: não era para verificar o corpo ou mesmo conferir ou checar, era para mover, soltar, levantar o mesmo. Movimentar.

Para achar o tônus do corpo, novo exercício, o qual o parceiro passivo, ficava no chão, estendido como o exercício "já foi", mas, no lugar de mover o corpo, o parceiro fica sobre o corpo imóvel do parceiro deitado. Primeiro foi a experiência de ficar de bruços, que foi razoavelmente simples, pois ficar sobre a coluna do outro não seria tão complicado, mas depois, decúbito dorsal, onde o parceiro deveria ficar com seus pés sobre o abdômen e o tórax do parceiro deitado, houve uma pequena complicação. Para as moças que estavam fazendo o exercício, ao saber do que se tratavam não se sentiram bem, pois seus seios ficam em seu tórax. Não seria pudor sobre o corpo, mas dor por ser colocado os pés em local tão sensível. Yudilevitch demonstrou como fazer, levando o pé que se encontrava no tórax acima dos seios delas, mais próximo ao pescoço, sem forçar de um lado ou de outros, por suas sensibilidades específicas. Os seios, na verdade, ficam bem mais abaixo, no tórax, do que as pessoas imaginam. Anatomicamente o exercício é possível sem maiores dificuldades. Fizeram, todos o exercício, com a troca, cerca de um minuto para cada participante ficar sobre o outro (figura 9). 


\section{$\begin{array}{llllll}D & O & S & S & I & \hat{E}\end{array}$ $V$ I $R$ A $A$ A AFETIVA}

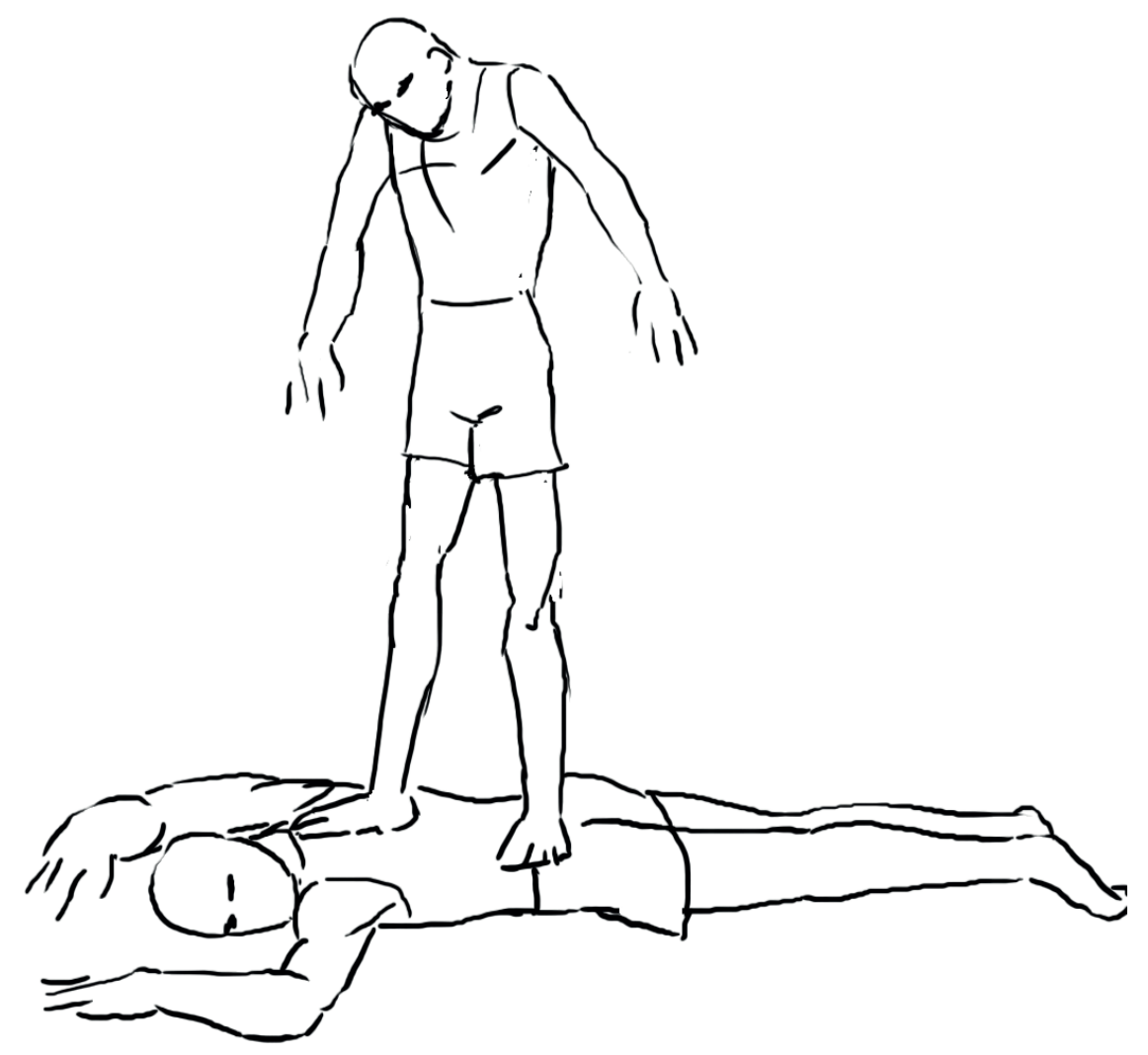

Figura 9: Andar sobre o corpo. Decúbito frontal. Arte do autor.

Continuando o exercício com corpos mortos "já foi", todos deveriam cair uns sobre os outros, se jogando (lentamente para não se machucarem), fazendo-se parecer uma montanha de corpos, pois ao ficarem sobre os outros, não podiam mais mover-se. Mesmo não havendo movimentos bruscos após o encontro dos corpos, o simples fato de um estar em cima do outro, trouxe novamente a busca da força, pois, se cada corpo tem cerca de cinquenta a setenta quilos, multiplicando pelos vários alunos aglomerados em um mesmo local, os 


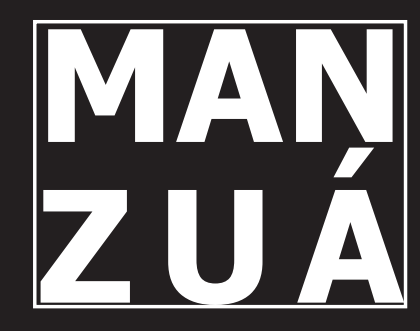

\section{O S S S I E $V$ I R A D $A$ AFETIVA}

que estavam embaixo, tinham que fazer força para sustentar os que estavam em cima, fazendo então ter que forçar o rosto na expressão de que estava doendo. Novamente buscamos nas palavras de Fernandes (2001) o sentido do corpo líquido, da força e do entrelaçamento dos alunos no mesmo espaço, quando a autora nos fala dos quatro fatores que oscilam nas gradações de polaridade: "fluxo, espaço, peso e tempo" (FERNANDES, 2001, p. 11). Pela força e pelas expressões faciais dos alunos, o professor fala "a dor não está no seu rosto. A dor está no local que você está sentindo. Force esse local, não seu rosto". Nunca tinha ouvido algo tão verdadeiro e ao mesmo tempo tão duro, vindo de um professor com nível técnico, dando aulas a graduandos, mas, mesmo assim, por não ter familiaridade com a dança, imaginei que esse tipo de frase é comum no meio pois todos estão fazendo força a todo o tempo.

Para o professor, aquela última atividade foi o complemento para finalizar sua aula, pois todos estavam prontos para fazer o último movimento. Para ele "dead fish", o peixe morto, que envolvia vários dos exercícios anteriormente criados. Justamente o que eu havia imaginado desde o início da aula: existiria algum exercício final que envolveria todos os outros. Uma atividade que todo o corpo seria envolvido e o cuidado que o professor tivera com o pescoço desde o início da aula, era primordial naquele momento. Utilizarei o esquema da figura 10 para melhor apreciação desse exercício. Deitado de bruços (Figura 10-A), por um impulso do braço no chão, o abdômen sobe (10-B) até ficar para trás, quando desce o mesmo em direção à perna (10-C), que também dobra com a força do movimento, fazendo o corpo ficar de lado nesse momento (10D) e depois, ficar decúbito dorsal (10-E). Dai, a perna é levantada (10-F) o suficiente para forçar todo o corpo girar (10-G) e voltar a ficar de bruços novamente (10$\mathrm{H})$, repetindo o movimento logo após o fim desse ciclo. Importante notar que ao voltar em cada um desses dois lados, o pescoço deve fazer a cabeça se proteger do solo, impedindo que se exista contusões ao fazer a atividade. $\mathrm{O}$ esquema pode ser visto na figura 10. 


\section{$D O S S I \quad \hat{E}$ $V \quad I \quad R \quad A \quad D \quad A$ AFETIVA}

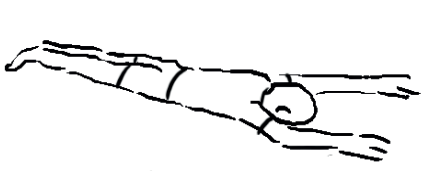

A

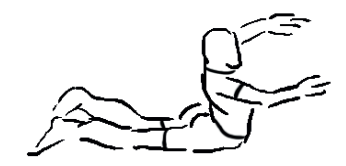

$B$

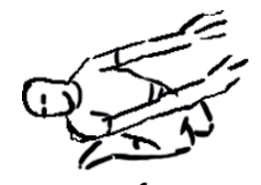

$c$

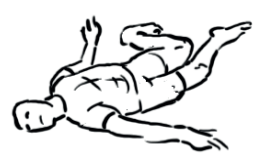

D
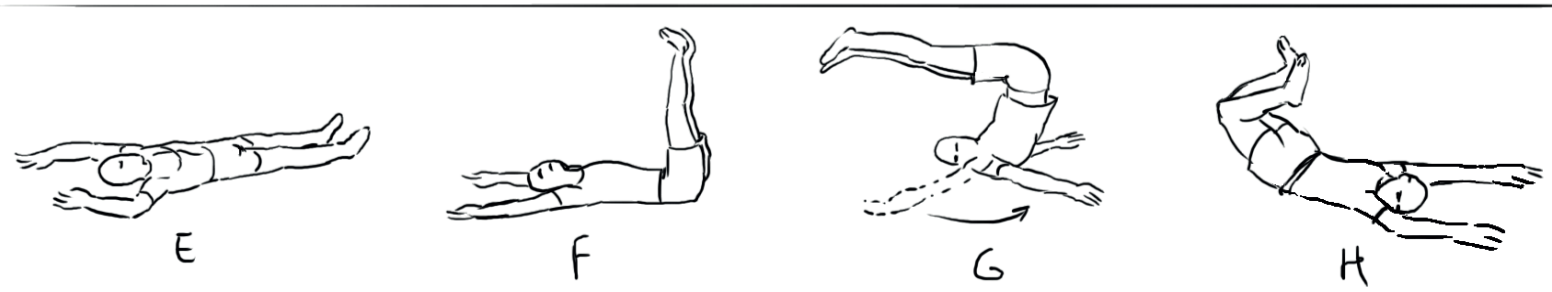

Figura 10: Exercício "peixe morto". Arte do Autor.

Para alunos com problemas ao fazer o movimento, outros ajudaram na parte de levantar a perna, justamente por ter que se fazer força ao levantar a mesma. Novamente, pela quantidade de alunos na sala, o balé de corpos foi criado, mas desta vez, alguns foram mais lentos, outros mais rápidos, o professor ajudando alguns alunos, nosso coordenador, que também fazia os exercícios, fez sua participação tanto fazendo as atividades, quanto ajudando alunos com dificuldades, terminando assim a parte dos exercícios.

Após as dinâmicas, houve uma roda de conversa para saber o que cada um sentiu, tanto os alunos que participavam da atividade, quanto aos que anotavam, filmavam, fotografavam o que acontecera. Falaram sobre a questão da força descomunal em vários dos exercícios, que tomou corpo com os estudantes e também a ajuda da suavidade da música ao tocar enquanto o exercício era criado. Não falei muito naquele momento. Observei tudo, vi o que acontecera, novamente a sensação de dejàvú veio a minha mente, reconhecendo aquilo que já havia visto, havia participado, como se eu antevisse tudo o que acontecera. Até o movimento da moça que estava fotografando, parecia que eu sabia onde ela ia estar dentro da sala, mas a sensação, ficou apenas comigo. 


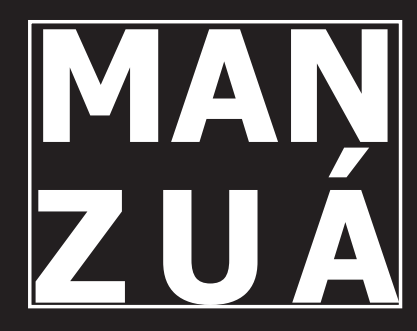

\section{O S S I E $V$ I R A D $A$ AFETIVA}

Senti-me frustrado por perceber tanto naquela aula e não dizer nada. Mas eu tinha que falar.

A aula, que fora de mais de duas horas e meia, terminara. Todos se ajeitaram, calçaram seus calçados e foram embora. Durante a ida para seu hotel, em uma carona que demos ao professor, Yudilevitch contou um pouco sobre sua vida, que era dançarino a vários anos, estava na graduação em seu país e participou de vários eventos de dança em várias partes do mundo. A apresentação de Natal e Israel ao mesmo tempo, fora mais um projeto, que ele fez com uma companhia de dança de seu país. Falou das várias experiências, que gostou da cidade e que continuaria o curso livre durante a semana. No carro, ouvindo toda a discussão entre ele e os outros dois companheiros do carro que trocamos caronas para economia financeira, novamente, veio a sensação de já viver aquele momento. Durante minha graduação, também pegava carona ao fim das aulas de dança e de teatro. Parece que tudo estava se repetindo e minha cabeça estava a mil. Ao mesmo tempo, sentia-me frustrado. Frustrado por, durante meu tempo na UFRN, Mesmo fazendo um curso de artes plásticas, era obrigado, pela grade curricular, fazer também cadeiras de fundamentos da dança e tudo o que aquele jovem professor passara, já havia feito. Isso à vinte anos ou mais e, principalmente, feito com tanta semelhança.

Frustrado também pelo fato que, se um cara vem de longe; por mais experiente que seja, aquele tipo de aula poderia ser feito por outros professores daqui de Natal e até dançarinos com experiência técnica suficiente para repassar informações, Pois quem aprender ensina e vice-versa (FREIRE, 1996). Um outro motivo foi o fato de, à vinte anos, na minha graduação, ao ter uma cadeira de fundamentos da dança e ao ter recebido, com mais sutileza, os mesmos tipos de aula dos atuais graduandos. Imaginei: depois de vinte anos, continua a mesma coisa? Os mesmos ensinamentos? Os mesmos movimentos? Assim, a sensação de dejàvú tomou conta de mim, parece que tudo que acontecera naquela noite já havia acontecido, de alguma forma, no passado. Será que aconteceu?

\section{FALSO RECONHECIMENTO}

Déjà vú, segundo estudiosos é uma ilusão que se tem a sensação de se viver alguma situação que aparenta ter- 


\section{MAN
ZUA}

\section{$\begin{array}{llllll}D & O & S & S & I & \hat{E}\end{array}$ $\begin{array}{llllll}V & I & R & A & D & A\end{array}$ AFETIVA}

se vivido antes. Bastante comum, grande quantidade de pessoas já passaram por essa sensação. Bergson (2006) fala explana que as pessoas podem presenciar tal experiência

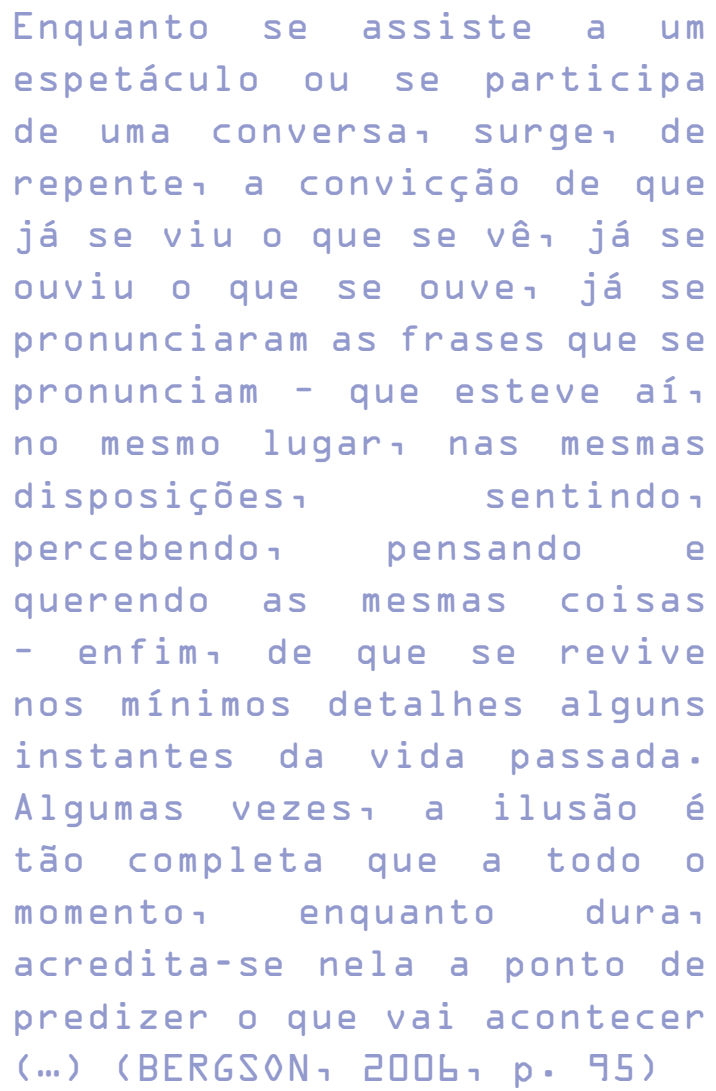

O mesmo autor discorre também que além do déjà-vu (“já visto” em francês), existe também o déjàvecu (“já experienciado") e este último é o que deveria ser pronunciado, pois não é exatamente o que você viu, mas o que você presenciou, ou presenciará, já que essa sensação é atemporal e pode, por que não? Ser uma sensação futura.

No entanto, esta sensação não passa disso mesmo: uma sensação. Inevitavelmente, as pessoas passam por experiências em sua vida que se repetem. Quantas vezes em sua vida você abriu uma porta? Quantas vezes andou na praia ou bosque ou uma rua específica? E quantas vezes, ao andar em algum lugar em outra parte do mundo ou de sua vida que algum lugar não tenha aparência de algo já feito? $\mathrm{O}$ cérebro serve para juntar, misturar, aglomerar informações em toda a nossa vida, mas em certas fases da mesma, existe um tipo de cansaço, descuido de informação interna por alguma emoção forte e o mesmo ficar abalado (na verdade o corpo todo fica abalado) ou mesmo aproximação de uma informação com outra, parecida e acaba-se tendo essa sensação de falso reconhecimento. Bergson fala também que existem características que chegam a modificar nossa forma de perceber o nosso redor, 


\section{Doriste $\begin{array}{llllll}V & I & R & A & D & A\end{array}$ AFETIVA}

como "uma representação, emoção ou estado de vontade" (BERGSON, 2006, p. 100) e que se supunha que o cérebro fosse um duplo em si mesmo, tendo duas percepções: uma no presente outra num passado representativo, "que produzisse duas percepções simultâneas, que uma podia, em certos casos, estar atrasada em relação à outra e, em razão de sua intensidade mais fraca, parecer uma lembrança" (BERGSON, 2006, p. 100) e a segunda sensação, adiantada "em relação à consciência e, se se manifesta a ela bruscamente, lhe traz uma lembrança daquilo que ela se ocupa em perceber" (BERGSON, 2006, p. 101), ou seja, a consciência não percebe algo do passado ou futuro, mas apenas o presente, a segunda sensação está em um patamar limítrofe, mas este nunca chega a ultrapassar a sensação presente, pois depende dela para "criar" sua versão mental.

Aqui chegamos a questão da experiência, ou momento experimentado, pois ao passar na rua uma pessoa específica, diz-se que se viu uma pessoa em algum lugar e não "Eu vi esta pessoa aqui, nas mesmas circunstâncias, em um momento de minha vida que era indistinguível do momento atual" (BERGSON, 2006, p.
102). Como o que temos em nossa vida é experiência, e essa é lembrada quando é importante, de alguma forma para nossa vivência social ou pessoal (BONDIA, 2002, DEWEY, 2010), o que se experiência ao reconhecer uma pessoa, mesmo sendo falso reconhecimento, vivemos um déjàvecu, pois isso foi ou é importante para nosso cérebro.

Creio não precisar maiores aprofundamentos sobre o falso reconhecimento, bastando, aqui, saber que existem estudos sobre o assunto e que o leitor, com essas primeiras impressões sobre tal, pode procurar novas e melhores explanações. Falei do mesmo, pois em várias fases de nossa vida, temos esses falsos reconhecimentos e que podemos nos aprofundar no que diz respeito essa sensação, se assim desejarmos.

\section{CONSIDERAÇÕES}

Meu foco aqui é mais voltado para a experimentação de uma noite de aula de dança e minhas impressões sobre a mesma. Se a experiência é o que nos passa algo e fica. Certamente esta noite ficou nos meus pensamentos, mas se não fossem as experiências anteriores, a vinte anos, nas aulas de fundamentos da dança 


\section{Do Binte $V$ I $R$ R A $A$ D A AFETIVA}

e do teatro, este texto talvez não tivesse saído. Meus questionamentos sobre ter-se aulas iguais às que eu tinha na graduação, depois de analisar por alguns dias minha frustração quanto a essa parte foi "por que não?", se eu tive a oportunidade de fazer as aulas, durante seis meses ou um ano, já que foram duas cadeiras acadêmicas; por que a nova geração de alunos não poderiam ter as mesmas experiências que eu tive? Afinal, se mudasse tanto as informações sobre o que é dançar e todos os alunos naquela aula, não passariam pelos exercícios de aquecimento ou préexpressivo, iriam direto fazer o balé, mas a vida e o aprendizado necessita de fases para poder ser vivenciada.

Eles poderiam, também ter uma aula com um dançarino local ou mesmo nativo? Sim. Mas as oportunidades são feitas para serem pegas. E que bom que foi uma experiência com pessoas de outros países. Só assim sabemos que o que se estuda na universidade, aqui em Natal, também é estudado em outras partes do mundo e não apenas na parte ocidental, como também no oriente próximo. Ter a figura do professor, próximo ao aluno, ajuda ao seu desenvolvimento, tanto na parte teórica quanto na prática. E se existe a experiência em sala de aula, os assuntos que os licenciandos podem ter com seus alunos, no futuro, pode ser de grande inspiração para novas possibilidades dentro de sala de aula.

Como falei no corpo do texto, eu tinha que falar sobre essa experiência. Meu pensamento sobre aquela noite vai ficar por muito tempo na minha memória, mas, ao repassar para você, leitor, ela está sendo compartilhada para que melhor seja visto por mais gente e quem sabe, a partir deste primeiro texto, possam surgir novas possibilidades de pesquisa sobre os exercícios aqui experienciados por mim e por todos os alunos que participaram daquela aula.

Justamente pelo fato de existir este artigo e pelo fato de ter sido uma aula de apenas um dia, certamente deixei de ver alguns detalhes na mesma. As anotações tiveram de ser rápidas, os desenhos mais rápidos ainda, tendo, certamente distorções no meu fazer artístico e dissertativo/descritivo. Sei que por mais que eu tenha produzido da melhor forma possível, não foi, nunca é, suficiente, mas é um começo. Dessa forma, outros autores ao ver este trabalho, podem melhorá-lo, criticá-lo e dar também sua 


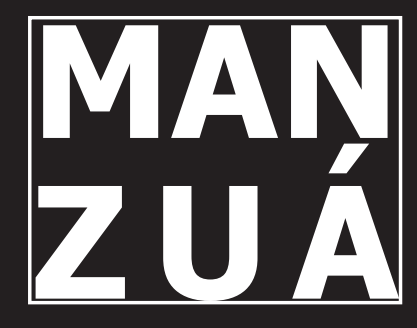

\section{$\begin{array}{llllll}D & O & S & S & I & \hat{E}\end{array}$ $\begin{array}{llllll}V & I & R & A & D & A\end{array}$ AFETIVA}

contribuição para a linguagem das artes cênicas serem cada vez mais elucidadas, registradas e divulgadas nos meios acadêmicos e sociais e incrementar esse conhecimento e perpassar para outros, já que, parafraseando Freire (1996) ensinar, é uma característica de nós, humanos.

\section{REFERÊNCIAS BIBLIOGRÁFICAS}

BERGSON ᄀ Henri. A lembrança do presente e o falso reconhecimento in Trans/ Form/Ação. Tradução: Jonas Coelhor São Paulor 200b $p$. ๆ5-】己l.

BONDíA 7 Jorge. Notas sobre a experiência e o saber de experiência. Universidade de Barcelona Barcelona Espanha.

CAUQUELIN contemporânea: uma introdução. Editora Martins Fontes : São Paulor Z005.

DEWEY 7 Jonh. Ter uma experiência. In: DEWEY ${ }_{7} \mathrm{~J}$. Arte como experiência. São Paulo: Martins Fontes z 20l] p.109-14 I .

FERNANDES ,

Ciane.
Esculturas líquidas: a préespressividade e a forma fluida na dança educativa (pós) moderna in Caderno Cedes, Anp XXI $n^{0} 53_{7}$ 200l.

FREIRE , Paulo. Pedagogia da autonomia: saberes necessários à prática educativa. São Paulo: Paz e Terra 1 199.

Vecchi, 1958.

CONNERTON, Paul. Como as sociedades se lembram. Lisboa: Celta Editora 1999.

EDITORA BRUGUERA. Razas Humanas. Espanha: Editora Bruguera 1955 .

GUATTARI 7 F. \& ROLNIK ${ }_{7} S$. Micropolítica: cartografias do desejo. Petrópolis: Vozes 7 l996 •

MANSANO , Sonia Regina Vagas. "Sujeito subjetividade e modos de subjetivação na contemporaneidade". In: Revista de Psicologia da UNESP. São Paulo , UNESP, в ( ᄅ). 2009.

PESSOA, Ida. Martha Rocha uma autobiografia. Editora

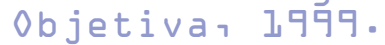

TAYLOR 7 Diana. Arquivo e Repertório: performance e memória social nas Américas. 


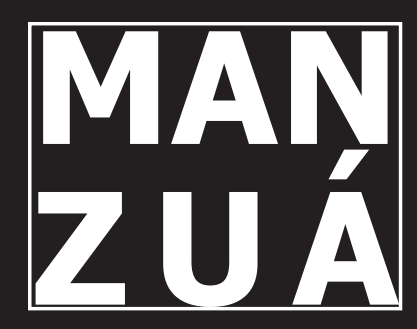

$\begin{array}{llllll}D & O & S & S & I & \hat{E} \\ V & I & R & A & D & A \\ A & F & E & T & I V & A\end{array}$

BH: Editora UFMG 2013.

MIMOSO, João Manuel. A agência portuguesa de revistas a ideia que valia milhões (195b-1957). : <http://www. historia.com $\cdot p t / A P R / A P R 5$. htm $>$.

\section{SITES}

http://www.deepwoods.org/ phantom.htm l

http: / / www.toonopedia.com/ mandrake.htm

http: / / ww w graphiqbrasil. com/cartunistas/alextoth. html.

ht t p: / / ww w. dynamite.com/ h t m l fil es/vi ewProduct. html? PRO = ClOb? ?

Este e APÊNDICE ensaios e resenhas minhas podem ser encontrados no meu perfil do site da Academia. edu disponível em: https:// independent. academia.edu/ LulaBorges 